\title{
Cihan Aktaş, Bacıdan Bayana (From Sister to Mrs.), İstanbul: İz Yayıncılık, 2016, $224 \mathrm{~s}$.
}

Betül Erken*

İlk basımı 2001'de yapılan Bacı'dan Bayana, Cihan Aktaş'ın değişen İslamcı kadın profilini kaleme aldığı bir tür inceleme-değerlendirme kitabıdır. 1995-2001 yılları arasında Müslüman kadının kamusal alan tecrübelerine dair yazdığı yazıların derlenmesinden oluşan kitap, siyasetten kamusal alandaki kadının konumuna ve İran sinemasına kadar farklı konular etrafında şekillenmektedir. 2001'de yayınlanan kitabın 7. baskısı 2016 yılında yapılmıştır.

Kitap, "Bacıdan Bayana" başlıklı ilk bölüm ve "Yeni Bir Kamusallık Arayışı" adlı altıncı bölümde Müslüman kadının kamusal alandaki serencamı üzerinde durmaktadır. Bu iki bölüm kitabın esas tartışma noktalarını içermektedir. Yetmişli ve doksanlı yıllar arasında İslamcı kadının yaşadığı tecrübeler, dönüşümler ve maruz kaldığı problemleri tartışan Aktaş, Müslüman kadının sahnenin dışına çekilmesi çabasını dönemin canlı tanığı olarak somut örneklerle sunmaktadır. Ele aldığı yetmişli yıllarda, İslamcı siyasal hareketlerin içindeki ailelerin kızları da kamusal alanda etkin olmaya başlamışlar, ancak meşruiyetlerinin kabul görmesi için kendilerini "Bacı" olarak adlandırıldıkları bir söylem içinde bulmuşlar ve bu söylemden de rahatsızlık duymamışlardır. Çünkü o dönemin muhafazakarlık algısında ancak bu şekilde kabul görebileceklerinin farkındadırlar. Bu dönemde kamusal alanda hayata tutunabilmenin imkânı olarak "Bacı" sıfatı; akrabalık dışı kadın erkek ilişkilerine güvenli bir sınır olarak çekilmiş, kendini muhafaza etmenin ve sosyal hayatta var olabilmenin anahtarı olarak görülmüştür. Seksenli yıllarda çeşitli dinî kaynakların ataerkil bir bakış ile okunması

* Marmara Üniversitesi İlahiyat Fakültesi Felsefe ve Din Bilimleri Doktora öğrencisi, mollabetul@gmail.com 
sonucu kadının evde kalması fikri baskın hale gelmiş ve kamusal alanda daha çok modernleşmenin temsilcisi "bayan” görünür olmuştur. Bacı söylemi de giderek değerini yitirmeye, kırsal alana ait bir anlama sahip olmaya ve özel alana hapsolmaya başlamıştır. Bayan ise Türkiye'deki modernleşme sürecinin giderek genişleyen gücünün temsilcisi olma yönünde anlam kazanmıştır.

Resmî ideolojinin bir unsuru olarak başörtüsü yasağı üzerinde duran Aktaş, kitabın yazıldığı yıllarda televizyon programlarında bu yasağı tartışanların içinde başörtülülerin olmamasını eleştirmektedir. Dinin kamusal görünümlerinin engellendiği 1990’lı yılların atmosferinde kamusal alanda yer alamadıkları için kendi haklarını savunamayan Müslüman kadınların haklarını savunmanın başörtüsüz kadınlara ya da erkeklere kalmasını bir problem olarak ele almaktadır. Bu problemli durum, Müslüman kadını haklarını savunan değil hakları savunulan edilgen bir duruma düşürmektedir. Çalışmasının iki bölümünde, başörtülü Müslüman kadının var olabilmek adına maruz kaldığı çileler üzerinde duran Aktaş, bugünü anlamak için dünün örneklerini sıralamaktadır.

Kitabın ana fikrini oluşturduğunu düşündüğ̈um birinci ve altıncı bölüm dışında kalan bölümlere kısaca değinmek gerekirse, "Sarı Barbie, Esmer Sara ve İkincil Kimlikler” başlıklı ikinci bölüm yazısında hâkim kültürün yerel kültürler üzerindeki baskısını Barbie bebek üzerinden işlemektedir. Yazar, Barbie bebekler aracılığıyla kız çocuklarına küçük yaşlardan itibaren nasıl vücut ölçülerine sahip olmaları gerektiğinin empoze edildiğinden bahsetmektedir. İran'da Barbie bebeğe bir alternatif olarak üretilen başörtülü ve gösterişten uzak görüntüsüyle Esmer Sara bebeğin hiçbir zaman vitrinlerde yer alamamasından yakınan Aktaş, Sara'nın ancak Barbie bebeğe benzediği ölçüde tercih edileceği ve benzediği oranda da ortaya çıkış amacından sapacağını belirtir.

"Yeni Azizeler: Her Zaman Otuz Yaşında Kadınlar" adlı üçüncü bölümde ise sistem eleştirisi yapan Aktaş, kadının bir tüketim nesnesi haline getirilmesi meselesi üzerinde durmaktadır. Ona göre görsel medya üzerinden sunulan ideal kadın görüntüsü, kadını modaya uymaya zorlayan ve belli kalıplara sokan bir algı oluşturur. 
Estetik, giyim, standart beden ölçüleri, gibi konular modern kadının özgürlügünün birer simgesi olarak görünürken aslında kadını sınırlandıran etkenlerdir. Bedene verilen önemin sonucu olarak kadının daima otuz yaşında görünmesi bir diğer ifadeyle hiç yaşlanmaması dikte edilir. Bu durum kadınları tabii olana karşı bir mücadelenin içine sokar. Kadın bedeninin piyasanın sunduğu ölçüler dahilinde mükemmeli yakalaması empoze edilir ve özgürlük şaşırtmaca bir kavramdan öteye gidemez.

Aktaş'in araştırma alanlarından biri olan İran'da toplumsal hayat, değişim, kadın konuları kitapta geniş yer bulmaktadır. İran ile Türkiye'nin farklı modernleşme modellerini yaşamış olmaları Aktaş’ı bu farklılığın Müslüman kadını nasıl etkilediği yönünde bir anlama çabasına sokmuştur. "İran'da Siyah Yorgunluğu" ve "İran Sinemasında Kadın Starlarla Gelen Model Meselesi” kitapta yer alan diğer iki bölümün başlığıdır. İran devrimiyle birlikte kadının tekrar özne olarak sahneye çıkmasının, kadın hakları ve kadının konumu hakkında düşünmeyi gerekli kıldığından bahseden Aktaş, İran devrimi ve sineması üzerinden kadın konusunun toplumsal dinamiklerini okumaktadır. İran devriminden sonra getirilen baş örtmeme yasağını da Türkiye'deki başörtüsü yasağıyla benzer şekilde değerlendirmektedir. İnanç eksenli kuralların siyasi bir yaptırımla uygulanmasının daha dindar bir toplum oluşturmayacağı gibi uygulanmamasının da daha modern bir toplum oluşturmayacağını belirtir.

İran'ın kadına yüklediği görevler, sinemada da peşini bırakmamakta ve ona daima biçim vermeye çalışmaktadır. Aktaş, İran devriminin kadın sembolü olarak Hz. Fâtıma'nın örnekliği öne çıkarılmaya çalışılsa da film yıldızlarının kadınlar tarafından model alındığına ve bu modelliğin toplumsal etkilerine işaret eder. Kadının bir film yıldızı olarak görünür hale gelmesinin önüne geçmeye çalışılmasına rağmen bu konuda başarılı bir sonuç elde edilememektedir. Buna karşın sinema, kadına dair birçok konuyu içinde barındıran ve bu konuda genişleyen bir sektör haline gelmektedir. Aktaş bu durumu kadının kamusallaşmasında önemli bir basamak olarak görmektedir. 
Başörtüsü meselesi Aktaş’ın gündeminde önemli bir yer teşkil etmektedir. Bu meselenin “problem” olarak görüldüğ̈ dönemlerde kitabı kaleme alması durumu anlaşılır kılmaktadır. Bugün başörtüsü ve başörtülüler, bazı kesimlerce halen nefret öğesi olarak görülse de geçmiş yıllar ile kıyasladığımızda kamusal alanda başörtüsü ile var olmak görece normalleşmiştir. Ancak yaşanan normalleşme, insanların geçmişte yaşadıkları problemlerin üstünü örtmektedir. Bu nokta, kitabın en önemli yerine tekabül etmektedir; zira bugün ile dünü kıyaslama imkânı sunması bakımından kitap tazeliğini halen korumaktadır. Kitap, yetmişli yıllardan itibaren dindar ve örtülü kadınların özellikle sosyal hayatta nasıl mücadele verdiklerini ve inançlarını taşımanın hiç de kolay olmadığı bir dönemde yaşadıklarını görmemizi sağlamaktadır. Aynı zamanda eser, Müslüman kadının kamusallaşırken ortaya koyduğu davranış kalıplarının karmaşıklığını da incelemektedir. Bir yandan dinî bir duruş sergilemeye çalışan bir yandan da kamusal alanın kendine has ahlakına muhatap olan kadınlar bu iki durum arasında bocalamaktadır. Bu kuşak acıyla beslenmiş ve bu acı onları diri tutmuştur diyebiliriz. Ancak bu konuda yirmi yılda büyük değişimlerin olduğunu da gözlemlemek mümkündür. Aktaş’ın açtığ yoldan ilerlediğimiz şu düşünceler zihnimizde oluşmaktadır: Muhafazakar televizyon kanallarında kadının sesi ve görüntüsünün mahsurlu olduğu düşüncesiyle kadınlara yer verilmediği bir dönemden başörtülü kadının birçok yerde görünür olduğu bir döneme gelinmiştir. Dinin kamusal alana çıkış mücadelesinin bir sonucu olarak Türkiye'de din toplum ilişkilerinde gözle görülür farklılaşmalar yaşanmaya devam etmektedir. Burası meselenin irdelenmesi gereken kısmıdır.

Aktaş, dönemi sosyolojik bir bakış açısıyla ele almaktadır ancak eleştirdiği olaylara kendisi de maruz kaldığı için kimi zaman kullandığı dil, günlük yazı diline kayabilmektedir. Aynı zamanda o dönemde etkin olan ancak günümüzde etkisini kaybetmiş isimlerden ve olaylardan bahsettiği için anlattığı bazı noktalar günümüz okuyucusu için tam anlamıyla açık olmasa da verdiği mesaj anlaşılmaktadır. Aktaş’ın yazar ve düşünür kimliğiyle seksenlerden itibaren Müslümanlar arasında bilinen bir isim olması, hatta kitaptaki tabirle bir "bacı" olarak kabul görmesi, ezilenlerin yanında yer 
alması ve seksenlerde İslamcı camia içerisinde "dava" insanı olarak tanınması yazısına da yansımıştır. Tespitleri oldukça sosyolojik olmasına rağmen kendi konumu ve tavırları yazılarına yansımakta, bu durum bazı noktalarda objektifliğini sarsmaktadır.

Bacı'dan Bayana Türkiye'nin kendi dinamikleriyle ilgilenen, kadın konusunu önemseyen, Türkiye'deki dönüşümü anlama çabasina giren bireylerin okuması tavsiye edilecek nitelikte bir kitap. Ancak bu eser bize, geçmiş tecrübeye ek olarak bugünün gelişmelerinin de analizlere dahil edildiği çalışmalara duyulan ihtiyacı hissettirmektedir. Özellikle Türkiye'de yaşanan dönüşümü takip eden küresel gelişmelerin hayatlarımızı dönüştürücü etkisi değerlendirilmelidir. Bu minvalde dinin kamusal hayattaki varlığı önündeki engellerin kalkmasına ek olarak özellikle iletişim teknolojisindeki gelişmelerin ve dijitalleşme sürecinin gözden uzak tutulmaması elzemdir. 